\title{
The Impact of Language Loss on the Māori Performing Arts
}

\section{Introduction}

By 1979, only 139 years after the signing of Te Tiriti o Waitangi (The Treaty of Waitangi) ${ }^{1}$, the loss of te reo Māori (the Māori language) was so great that it was believed that it would suffer language death. ${ }^{2}$ This can be attributed to the State policy of assimilation established in 1847 that eroded the status of the language.

Te reo Māori is considered to be the core of Māori culture, as illustrated in the following Māori proverb:

Ko te reo te mauri o te mana Māori

The Māori language is the life force of the Māori people

The decline of te reo Māori since the arrival of the Pākehā (non-Māori of European descent) has affected, and in many cases continues to affect, every facet of Māori society. One such facet is the field of Māori performing arts, ngā mahi a Tāne-rore me Te Rēhia.

The Māori performing arts, like all other aspects of Māori culture, has evolved at great speed since the arrival of the Pākehā. However, not all of the changes have been progressive. One of the most devastating changes for the performing arts has been the decline of te reo Māori. For example, it follows that as the number of Māori people fluent in te reo Māori has declined, so too have the number of potential composers of waiata (song, chant) and haka (posture dances of various types). Experts in this field have continually placed emphasis on the language and the important role and function that it plays in maintaining the mana (authority, power, influence, prestige, status) of the Māori performing arts.

Rachael Ka'ai-Mahuta is a PhD student and Assistant Lecturer (part-time) in Te Ara Poutama, Faculty of Māori Development, AUT University. Her doctoral thesis, which will examine the political content and nature of Māori waiata and haka compositions. 
This article will focus on the impact that language loss has had on the Māori performing arts drawing on the research undertaken for my Master of Arts thesis completed in 2005.

\section{Language and the Māori Performing Arts}

The Māori language is at the heart of Māori society and is connected to all other cultural concepts within the Māori world. The holistic nature of the Māori world-view and the inter-connectedness of Māori cultural concepts is best illustrated by the late John Te Rangiāniwaniwa Rangihau in a model that he developed to help non-Māori to understand the Māori world-view more effectively.

Ka'ai argues that the placement of the Māori world at the very centre of the Rangihau model, and Pākehā culture on the periphery, reflects a culturally specific framework from which to understand a Māori world view and which some academics, like Ka‘ai, call Kaupapa Māori Ideology:

Rangihau locates the Pākehā on the periphery of the cultural framework/model thus depicting an interface with the Pākehā world. This is an important feature of the model as it does not propose that Māori be assimilated, integrated or subsumed by non-Māori into the dominant culture. ${ }^{3}$

Reo is one cultural concept that Rangihau has included as the Māori language is, for Māori, the traditional vessel for the transmission of knowledge including tribal history, politics, and environmental knowledge. Furthermore, the Māori language is also the traditional form of expression. This illustrates the direct and parallel link to the performing arts as one such form of expression that relies on te reo.

According to Ka'ai, 4 there are many other cultural concepts that Rangihau does not mention. These can be added to the model as further layers. Performing arts can be linked with many of the concepts in the Rangihau Model such as hui (meeting, gathering), tangihanga (rites for the dead), marae (space in front of the meeting house and the surrounding area), hākari (feast), reo (language), kawa (protocol, procedure), and politics, whether it be the actual performing of waiata, in its many forms, or through composition in the Māori language which develops a political theme for performance. 


\section{The origins of haka}

The Māori language was traditionally an exclusively oral language. Traditional Māori waiata and haka can be described as the traditional newspapers and history books of Māori society. It is logical then that the origin of the Māori performing arts is located in an oral Māori historiography ${ }^{5}$.

From a Māori world view all things in the natural world, including humans and different human activity, have a whakapapa (genealogy). According to Māori oral history, the whakapapa of the performing arts is traced back to Tama-nuite-rā (the sun). Tama-nui-te-rā had two wives, Hine-takurua, who has been referred to as the winter maiden, and Hineraumati, the summer maiden, with whom he had a son called Tāne-rore. It is said that Tāne-rore would dance for his mother. On hot summer days the air that rises from the ground trembles and this is personified as te haka a Tāne-rore (the dance of Tāne-rore). In modern day performances the wiri (continuous trembling or shaking of the hands) is an acknowledgement of this ancestor and his dance. ${ }^{6}$

The fact that this story has been relayed to countless generations is one example of the perseverance and strength of the Māori language, and it is also a testament to the importance of the language in transmitting knowledge. Furthermore, stories such as this one are often difficult to translate, as some of the emphasis, interpretation and metaphoric language are lost in translation. There are many other stories that have been passed down through the generations that describe the origins and the various usages of the Māori performing arts. However, this story is widely accepted by Māori across many tribes as the story that best describes the origins of haka.

\section{Traditional contexts of the Māori Performing Arts}

The importance of the Māori language is most evident on the marae. ${ }^{7}$ Here we see traditions that have been passed down from generation to generation over hundreds of years. Hence the reason the marae has been described as the bastion of Māori culture. However, this would not be possible without the Māori language, as language and culture are inherently linked. All aspects of tikanga (protocols and customs) on the marae rely on the Māori language. Every step of the pōhiri 
(ritual of encounter) from the karanga (the ceremonial female call of welcome) to whaikōrero (oratory) would be lost without the language. According to Dr Tìmoti Kāretu:

Only the best karanga women invite the guests onto the marae ... these women are the best in terms of their voice, their ability to express themselves imaginatively by making allusions to mythology and proverb, where appropriate. This is also true of the orators - only the most articulate, the most eloquent and the most learned rise to speak. ${ }^{8}$

One cannot be articulate and eloquent, or make imaginative allusions to mythology and proverb, in a language that one does not speak.

\section{The impact of colonisation on the Māori language}

The decline of the Māori language is the result of colonisation. From its inception, the New Zealand Government has continually passed legislation that has been detrimental to the Māori language and furthered the Government's agenda of assimilation and language domination. As a result, the loss of the Māori language was so great it was believed that it would die out.

Languages die because they are no longer spoken. This happens because their speakers die out without passing them on to the next generation. Only rarely is this because of the extinction of an entire society or race. Usually it happens because from generation to generation (it takes only three or four) the speakers shift to another language. Languages do not die natural deaths. They do not fade away without outside influence. Languages are killed by other languages. ${ }^{9}$

The mechanism of the Government's agenda of assimilation and language domination was the State education system. This was, therefore, the primary cause of Māori language loss. In 1847, the Education Ordinance Act was introduced in order to aid the assimilation process. ${ }^{10} \mathrm{Sir}$ George Grey introduced the Education Ordinance Act, as he believed that it would speed up the process of assimilation by insisting that English be the medium of instruction in schools. The Education Ordinance Act also encouraged the establishment of more boarding schools, particularly industrial training boarding schools, as they would take the 
children away from the "demoralising influences of their villages", thereby "speedily assimilating the Maori to the habits and usages of the European".'11

Furthermore, under the Education Ordinance Act mission schools were to be subsidised with public funds, perhaps as an incentive to carry out the Government's aims. ${ }^{12}$ The Act resulted in the establishment of new church boarding schools between 1848 and 1852. These schools separated Māori children from their whānau, therefore separating them from their language and cultural base and increasing the chance of language loss and assimilation.

The Education Ordinance Act was the first formal move towards language domination and hegemony. There were many other acts of legislation that followed that have been equally detrimental to the Māori language. In both direct and indirect ways, the legislation passed regarding the establishment and evolution of the New Zealand education system has created amongst many Māori families one of the greatest, if not the greatest injustice of them all - the inability to speak one's own native tongue.

According to Glynn, 'Participation in mainstream education has come for Māori at a cost of their own language, culture and identity'. ${ }^{13}$ This is evident when one considers the statistics. In 1900, over ninety per cent of Māori children started school with te reo Māori as their first language. However, by 1960 this had fallen to twenty-five per cent. ${ }^{14}$ By 1979, the loss of the Māori language was so great that it was believed that it would become extinct if nothing was done to save it. ${ }^{15}$ According to Ka'ai-Oldman, by 1984 the number of children entering primary school with Māori as their first language was most likely less than two per cent. 16

Further evidence of the success of colonial tools, such as language domination, can be found in the fact that New Zealand is among the most monolingual countries in the world. It is estimated that ninety to ninety-five per cent of New Zealanders cannot speak any other language apart from English. ${ }^{17}$ This percentage is a lot greater than other primarily English speaking nations such as Britain, the United States of America, Canada, and Australia. ${ }^{18}$ 


\section{The impact of language loss on the performing arts}

The loss of the Māori language has had a major affect on the Māori sense of identity. According to Walker, 'A basic component of Māori identity is the concept of Māoritanga, which incorporates ... cultural traits such as language'.19 Furthermore, the language domination that has occurred in Aotearoa/New Zealand since the establishment of the Education Ordinance Act has served to strip Māori of our primary tool for expressing ourselves. This in turn has had a profound impact on the performing arts. If language loss occurs in a certain region then so too does the loss of potential composers. The effects of this are evident today. According to Wharehuia Milroy (2004, personal communication), there are few composers today that can live up to the legacy left behind by the prolific Māori composers of the past.

Language loss has also meant a lack of understanding of the meaning of waiata and haka. If a performer does not understand the meaning of what they are performing it is impossible to convey the right emotion and place emphasis in the right place. ${ }^{20}$ Tìmoti Kāretu raises his concern regarding this matter:

Each generation changes and what one did not accept another does. As conventions and philosophies of haka are ignored for the sake of applause and victory, so the whole art becomes shallow ... The language will continue to be the difficult issue for most of the young performers but for haka to be meaningful and to survive the young performer must know what is being said, how to interpret what is being said and how to imbue that interpretation with passion and panache. Not to do so, is to do haka and our ancestors an injustice. ${ }^{21}$

The Māori renaissance of the 1970s and 1980s produced many outcomes that have been beneficial to te reo Māori, and subsequently to the performing arts. One positive outcome from this time period was the establishment of Kaupapa Māori education, that is, immersion Māori language education. After many years of being affected by cultural subordination and language domination, and with no indication of positive action by the State, Māori families and communities took matters into their own hands. That is, Māori decided to start reversing the cycle of language decline within their society by immersing their children in a bilingual environment through the introduction of Kaupapa Māori education. ${ }^{22}$ 
Another positive outcome of this time period was the emergence of performing arts festivals that became particularly popular at this time, following a huge rural to urban migration of Māori people. These festivals and the many kapa haka (Māori performing arts groups) that were established at this time provided a link for Māori families living in the city to their culture and subsequently provided contact, regardless of how little, to the language. ${ }^{23}$

The combined positive result of the language and cultural renaissance of this time period has been an increase in the number of Māori language speakers, and therefore an increase in the number of potential performers and composers.

\section{Conclusion}

During the research process for my MA thesis, I interviewed four exponents of the performing arts: Timoti Kāretu, Wharehuia Milroy, Pae Ruha, and Te Ripowai Higgins. I asked them all what, in their view, was the most important component of the Māori performing arts. They were unanimous in their answer - the language and, more specifically, the quality of the language; 'ko te kupu te mea nui ... ko te kupu te matua ... ko te kupu i te tuatahi ... ko te mea nui kē hoki i roto i ngā mahi katoa ko te kupu'.24 Furthermore, they all agreed that the language was the aspect of performing arts that required the most attention. Again, this can be attributed to language loss in that Māori are victims of circumstance and have sadly lost many fluent speakers of the language.

It seems appropriate to echo the sentiments of my informants in that they are unyielding and uncompromising in their expectations of the standard of Māori language that we should all strive to attain. They are known for encouraging Māori communities to be vigilant and single minded in the pursuit of language excellence.

On a final note, I want to recall one of our nation's most cherished kaumātua, Tā Hēmi Henare (Sir James Henare), who when giving evidence in 1986 for the Waitangi Tribunal25 Claim relating to the Māori Language said:

If the language dies as some predict, what do we have left to us? Then, I ask our own people who are we? 
'Language', according to Oliver Wendell Holmes, 'is a solemn thing, it grows out of life, out of its agonies and its ecstasies, its wants and its weariness. Every language is a temple in which the soul of those who speak it is enshrined.' Therefore, the taonga, our Māori language, as far as our people are concerned, is the very soul of the Māori people. What does it profit a man to gain the whole world but suffer the loss of his own soul? What profit to the Māori if we lose our language and lose our soul? Even if we gain the world. To be monolingual, a Japanese once said, is to know only one universe...'.26

\section{Notes}

1 The Treaty of Waitangi is the founding document of Aotearoa/New Zealand. It was established as a partnership between the British Crown and Māori as the Indigenous people. It was signed on the 6th of February 1840 and has been the focus of controversy ever since. This has stemmed from the fact that two versions of the Treaty were produced. The Māori text which was signed by both Māori and the Crown was translated from the English text by a non-Indigenous missionary. However, the translation was not at all a correct interpretation of the English text. It is the English text which has been used by the Crown as the definitive version and this is the cause of contention to this day between Māori and non-Māori.

2 R. Walker, Ka Whawhai Tonu Matou, Auckland, 1990, pp. 147-8.

3 T. M. Ka'ai, 'Indigenising the Academy - Indigenous Scholars as Agents of Change', unpublished paper, 2005.

Op. cit.

5 It is important to note that there are various tribal differences in the ways the stories have been passed down from generation to generation and that the version that follows may vary from other versions.

6 R. Ka'ai-Oldman, 'Tākina ko au, tākina ko koe! Te Āhuatanga o te Whakataetae Kapa Haka', MA thesis, University of Otago, 2005, p. 22.

7 The marae is a place where meetings and important events pertaining to Māori families take place such as welcoming and hosting visitors, weddings, birthday celebrations, political meetings, Māori performing arts practices, religious services, educational conferences and tangihanga. In a contemporary context, the term marae is used to refer to a complex that includes whare tipuna (ancestral house), wharekai (dining hall), wharepaku (ablution block) and surrounding lands (Higgins \& Moorfield 2004: 73).

8 T. Kāretu, Haka! Te Tohu o te Whenua Rangatira, The Dance of a Noble People. Auckland, 1993, p. 84.

9 A. Bell, 'The Politics of English in New Zealand', in G. McGregor \& M. Williams. (eds) Aspects of Language and Literature in New Zealand. University of Waikato Winter Lecture Series of 1990. Auckland, 1990, p. 67. R. Walker, p. 146

Ibid., p. 46.

Ibid., p. 146

T. Glynn, 'Bicultural Challenges for Educational Professionals in Aotearoa', in Waikato Journal of Education. Volume 4,1998, p. 4. 
14 T. Ka'ai-Oldman, 'A History of New Zealand Education from a Maori Perspective', in W. Hirsh \& R. Scott. (eds) Getting It Right-Aspects of Ethnicity and Equity in New Zealand Education. Auckland: The Office of Race Relations Conciliator, 1988, p. 24

15 R. Walker, pp. 147-8.

16 T. Ka'ai-Oldman, 'A History of New Zealand Education from a Maori Perspective', p. 24.

A. Bell, p. 66.

18 Op. cit.

19 R. Walker, Ngā Pepa a Ranginui - The Walker Papers. Auckland, 1996, p. 25.

R. Ka'ai-Oldman, 2005 , p. 68

T. Karetu, p. 13.

R. Ka'ai-Oldman, 1988, p. 27.

R. Ka'ai-Oldman, 2005, p. 64

Quoted in ibid., pp. 87-8.

This is commonly known as the WAI11 claim.

6 (Waikerepuru and Nga Kaiwhakapumau I Te Reo Incorporated Society, 1986:40-41 cited in T. Ka'ai 2004, p. 202. 